DOI: $10.19195 / 0137-1134.109 .16$

\author{
ŁUKASZ MACHAJ
}

Uniwersytet Wrocławski

\title{
DOKTRYNALNA LEGITYMIZACJA IDEI WOLNOŚCI SŁOWA
}

Poszanowanie wolności wypowiedzi jest jedną z najbardziej fundamentalnych zasad aksjologicznych, które winny być respektowane w każdej społeczności politycznej aspirującej do określania siebie mianem liberalno-demokratycznej. Centralna rola swobody ekspresji w takowych porządkach ustrojowych wydaje się powszechnie rozpoznawalna. Jak przekonująco pisze Fred R. Berger,

nie ma szybszej drogi do „udowodnienia” nowożytnemu liberalnemu demokracie niedemokratyczności danego systemu, a także jego niesprawiedliwości, aniżeli wskazanie, że państwo to nie respektuje wolności wypowiedzi. Nawet organizowanie w takim państwie wyborów nie zapewnia mu akceptowalności, jeżeli tym procedurom wyborczym nie towarzyszą swoboda debaty oraz wolność wyrażania poglądów sprzecznych ze stanowiskiem rządzących ${ }^{1}$.

Przynajmniej na płaszczyźnie ogólnej i werbalnej kwestia ta jest przedmiotem konsensusu pomiędzy wszystkimi mainstreamowymi nurtami politycznymi w demokracjach typu zachodniego. Otwarte podważanie wolności słowa czy też proponowanie wprowadzenia cenzury byłoby dla orędowników tego rodzaju koncepcji prologiem ich rychłego politycznego końca. Podkreślić jednak należy bardzo ogólny (czy wręcz powierzchowny) wymiar tego konsensusu. Zasada wolności słowa odnosi się wszak do niemal niezliczonej mnogości nader zróżnicowanych stanów faktycznych. Przez jej pryzmat można, a nawet trzeba, rozpatrywać normatywne rozwiązania dylematów związanych z demonstracjami ulicznymi, bojkotami organizacji i przedsiębiorstw, reklamami i stawianiem billboardów w przestrzeni publicznej, korzystaniem z nagłośnienia w miejscach publicznych, popieraniem przeprowadzenia przy użyciu siły rewolucji społeczno-politycznej i głoszeniem poglądów „wywrotowych” bądź ,antypaństwowych”, profanowaniem symboliki narodowej, dystrybucją ekspresji poprzez sieci komputerowe, istotą oraz granicami ochrony przysługującej twórcom na podstawie norm prawa autorskiego, wypowiedziami o charakterze pornograficznym i obscenicznym, przestępstwami zniesławienia oraz zniewagi, dostępem do forów publicznych, wyrządzaniem ekspresją różnorakich szkód psychicznych, podżeganiem do popełnienia czynu

${ }^{1}$ F.R. Berger, Introduction, [w:] idem, Freedom of Expression, Belmont 1980, s. 1. 
zabronionego, szantażowaniem lub formułowaniem gróźb karalnych, propagowaniem ideologii totalitarnych, głoszeniem tez rasistowskich, „homofobicznych” i ksenofobicznych, granicami prywatności itd. ${ }^{2}$ Jeżeli podejmujemy próbę głębszej analizy i wniknięcia pod powierzchnię generalnego konsensusu, okazuje się, iż szczegółowe interpretacje znaczenia i zakresu zasady wolności słowa, formułowane przez uczestników debaty publicznej o zróżnicowanych poglądach politycznych czy ideowych, pozostają niejednokrotnie rozbieżne. Co więcej, w praktyce życia społecznego często mamy do czynienia z sytuacją, w której przedstawiciele — mówiąc umownie - lewicy i prawicy dążą do nieustannego cenzurowania się nawzajem ${ }^{3}$. Podkreślmy także, iż wnikliwa analiza prawa stanowionego i praktyki jego stosowania w poszczególnych krajach o jednoznacznie liberalno-demokratycznym profilu często prowadzi do konkluzji, że zarówno ustawodawca, jak i sądy czy organy administracyjne nie są szczególnie skłonne do przyznawania ochrony prawnej wypowiedziom o charakterze „obrażającym, oburzającym, wprowadzającym niepokój w państwie bądź też w części społeczeństwa"4, co jest, w mojej ocenie, kwintesencją i ratio zasady wolności słowa (ekspresja popularna takiej protekcji zazwyczaj nie potrzebuje). W konsekwencji tych procesów to jednostkowe uprawnienie staje się często nudum ius.

$\mathrm{Z}$ wymienionych wyżej powodów celowa zdaje się nieustanna rekapitulacja pewnych doktrynalnych uzasadnień usprawiedliwiających ideę swobody wypowiedzi. Uświadomienie sobie oraz pogłębione zrozumienie ideowych i aksjologicznych przesłanek legitymizujących ochronę wolności słowa pozwala decydentom na konsekwentne oraz ufundowane na jasnych pryncypiach (ergo sprawiedliwe) rozwiązywanie wielu różnych szczegółowych problemów związanych z konkretnymi stanami faktycznymi. Nawet jeśli przedstawione niżej argumenty miałyby podlegać refutacji, to i tak zarysowany tutaj cel mógłby zostać urzeczywistniony. Do najważniejszych ideowych legitymizacji swobody wypowiedzi trzeba zaliczyć deontologiczne uzasadnienie $\mathrm{z}$ indywidualnej autonomii i konsekwencjalistyczne usprawiedliwienia związane z poszukiwaniem prawdy, podstawowymi pryncypiami ustroju demokratycznego, postępem w rozmaitych dziedzinach życia oraz zasadą tolerancji. Argumenty te przynajmniej pretendują do uniwersalności, tj. są adekwatne do ekspresji jako takiej, dotycząc wielu zróżnicowanych rodzajów aktywności komunikacyjnej ${ }^{5}$. Warto również zaznaczyć, że przywołane argumenty - choć dystynktywnie odrębne pod względem konceptualnym oraz ufundowane na osobnych podstawach etycznych — nie są bynajmniej przeciwstawne oraz

2 Por. R.A. Smolla, Free Speech in an Open Society, New York 1992, s. 18-19.

${ }^{3}$ Por. N. Hentoff, Free Speech for Me but not for Thee: how the American Left and Right Relentlessly Censor Each Other, New York 1993, s. 1 n.

4 Por. orzeczenie Europejskiego Trybunału Praw Człowieka w sprawie Handyside vs. Wielka Brytania, 1 EHRR 737 (1976).

5 Zob. W. Sadurski, Freedom of Speech and Its Limits, Dordrecht 1999, s. 8-35; T.I. Emerson, The System of Freedom of Expression, New York 1970, s. 6-7. 
mogą się nieproblematycznie uzupełniać. Żaden z nich nie sugeruje też w sposób automatyczny, że wolność słowa musi być traktowana w kategoriach absolutnych jako prawo pozbawione jakichkolwiek granic czy konturów. Chciałbym równocześnie podkreślić, że moim celem jest tu wyłącznie streszczenie powyższych uzasadnień, a nie ich pogłębiona krytyczna analiza.

Argument z jednostkowej autonomii zakłada, iż prawo do swobodnego wypowiadania się jest istotną częścią składową wolności indywidualnej. Dla celów niniejszego artykułu nie jest konieczne rozważanie uzasadnień wyjaśniających celowość ochrony autonomii jednostki jako takiej. Takie założenie może zostać przyjęte jako niepodlegający dowodzeniu aksjomat, który jest ogólnie niekontrowersyjny w każdej zbiorowości politycznej odwołującej się do wartości liberalnych. O ile taka koncepcja może podlegać uprawomocnianiu w różny sposób (np. poprzez odwołanie się do paradygmatu iusnaturalistycznego, przywołanie Rawlsowskiej sytuacji pierwotnej, oparcie się na perfekcjonistycznym liberalnym moralizmie itd.), o tyle finalna konkluzja nie budzi wątpliwości. Bodaj najdobitniej przedstawił ją John Stuart Mill w swoim fundamentalnym opus magnum:

Gdyby cała ludzkość z wyjątkiem jednego człowieka miała pewien pogląd, a tylko ten jeden człowiek zajmowałby przeciwne stanowisko, ludzkość nie miałaby większego prawa do uciszenia tej jednej osoby aniżeli ona, gdyby posiadała taką możliwość, do uciszenia ludzkoścíi

Powyższa teza jest oczywiście oderwana od konkretnej merytorycznej treści poglądów wyrażanych przez ogół i zbuntowaną jednostkę. Jej podstawą jest założenie, że dany pogląd jest własnością jego posiadacza, pozbawienie którego prawa do głoszenia swoich opinii jest w gruncie rzeczy ekwiwalentem kradzieży materialnej własności. Trzeba podkreślić, że poszanowanie wolności słowa nie jest w powyższym ujęciu traktowane jako instrument służący indywidualnej samorealizacji, rozwojowi niezależności czy moralnej samoświadomości człowieka. Teza taka wydaje się zresztą nie do utrzymania — istnieją wszak rodzaje ekspresji, które w najmniejszym stopniu nie przyczyniają się do urzeczywistnienia tak zarysowanego celu (nienawistny dyskurs rasistowski, kłamstwo oświęcimskie, pornografia, wulgaryzmy itd.). Respektowanie swobody wypowiedzi stanowi natomiast jeden z najbardziej fundamentalnych przejawów szacunku wobec osoby ludzkiej, będącej odrębnym podmiotem, obdarzonym godnością i mającym podstawowe prawo do stanowienia o sobie ${ }^{7}$. Mówiąc expressis verbis, wolność komunikowania się jest doniosłym aspektem osobowej autonomii, a nie sposobem jej osiągnięcia. Jak przekonująco twierdzi Wojciech Sadurski, poszukiwanie doktrynalnego usprawiedliwienia wolności słowa $\mathrm{w}$ uprawnieniu jednostki do samorealizacji stanowi logiczną konkluzję liberalnego paradygmatu, zgodnie z którym ,autonomia działania jest $\mathrm{z}$ reguły ważniejsza, jako dobro samoistne, niż konkretne rezultaty danego dzia-

6 J.S. Mill, On Liberty. The Subjection of Women, New York 1879, s. 35, www.libertyfund. org (dostęp: 15.11.2012).

7 Por. R. Dworkin, Justice in Robes, Cambridge 2006, s. 70. 
łania"8. Z wolności można korzystać źle bądź dobrze; jej prawomocne moralnie ograniczenie musi być jednak uprawomocnione innymi (dodatkowymi) przesłankami (np. poprzez millowską zasadę krzywdy) prócz prostej konstatacji o „niewłaściwym” czy „niemoralnym” sposobie czynienia użytku ze swobody komunikacji przez jej dysponenta. Jeśli pod pojęciem autonomii rozumieć będziemy — za Thomasem Scanlonem - również ,suwerenność w decydowaniu o swych przekonaniach i w ważeniu konkurencyjnych argumentów przemawiających za bądź przeciw podjęciu jakiegoś działania"9 to wskazana uprzednio zależność staje się oczywista.

Antyutylitarny i niekonsekwencjalistyczny charakter argumentu z autonomii jednostki został klarownie przedstawiony przez prominentnego reprezentanta zorientowanego liberalnie nurtu współczesnej amerykańskiej filozofii prawa Ronalda Dworkina. W przekonaniu jurysty swoboda ekspresji stanowi zasadniczy atrybut każdej sprawiedliwej społeczności politycznej, której podstawowym fundacyjnym pryncypium musi być bezwzględne rozpoznanie dorosłych i nieupośledzonych psychicznie obywateli jako

odpowiedzialnych podmiotów moralnych. Wymóg ten ma dwa aspekty. Po pierwsze, ludziom odpowiedzialnym moralnie zależy na samodzielnym dochodzeniu do ustalenia, co jest dobre, a co złe w życiu czy w polityce lub co jest prawdą, a co fałszem w sprawach sprawiedliwości i wiary. Władze obrażają obywateli i odmawiają im odpowiedzialności moralnej, gdy odgórnie dekretują, że nie można na tyle zaufać obywatelom, aby umożliwić im zapoznanie się z poglądami skłaniającymi ku treściom niebezpiecznym czy niemoralnym. Jako jednostki zachowujemy [...] godność tylko wtedy, gdy utrzymujemy, że nikt — ani urzędnik, ani większość — nie ma prawa, by powstrzymać nas przed poznaniem danej opinii dlatego, że nie jesteśmy gotowi do jej przyjęcia.

Po drugie, jak akcentuje Dworkin, jednostki są również odpowiedzialne za przekazywanie swych przekonań

innym osobom z szacunku i troski dla nich oraz z przemożnego pragnienia poznania prawdy, służby sprawiedliwości oraz ochrony dobra. Władze naruszają oraz kwestionują tenże wymiar osobowości moralnej, dyskwalifikując niektóre osoby co do możliwości realizowania takiej odpowiedzialności wyłącznie na tej oto podstawie, że ich przekonania czynią z nich [...] bezwartościowych

uczestników tej społeczności politycznej, niezasługujących na posiadanie równego innym prawa do partycypowania w społecznym dyskursie.

Dworkin utrzymuje, iż państwo usiłujące pozbawić człowieka wskazanych „atrybutów odpowiedzialności moralnej” faktycznie niszczy wszelką „treściową podstawę swego roszczenia do legitymowanej władzy nad jednostką". Amerykański filozof prawa podkreśla też wielopłaszczyznowość prawa do wolności słowa z punktu widzenia indywidualnej autonomii:

Podobnie wielkie zło dzieje się, gdy rząd zakazuje wyrażania pewnych postaw społecznych czy gustów, jak ma to miejsce wtedy, gdy wyraźnie cenzuruje wypowiedzi polityczne; obywatelom

8 W. Sadurski, Prawo do wolności słowa w państwie demokratycznym (zagadnienia teoretyczne), „Państwo i Prawo” 1992, nr 10, s. 5.

9 T. Scanlon, A theory of freedom of expression, „Philosophy \& Public Affairs” 1, 1972, s. 215. 
przysługuje takie samo prawo do przyczyniania się do formowania klimatu moralnego lub estetycznego, jak prawo do uczestnictwa w polityce ${ }^{10}$.

Podsumowując, w ujęciu Dworkina uprawnienie do swobodnego formułowania określonych wypowiedzi powinno przysługiwać obywatelom nawet wówczas, kiedy społeczeństwo jako całość uzyskałoby więcej korzyści, gdyby dana ekspresja nie była tolerowana ${ }^{11}$. Dodajmy, że udzielenie aprobaty temu stanowisku nie implikuje konieczności przyjęcia perspektywy absolutystycznej, ale nakazuje tylko, aby ograniczanie wolności słowa było legitymowane silniejszymi racjami niż każdy negatywny rezultat kalkulacji społecznych zysków oraz strat płynących ze swobody formułowania ekspresji określonego rodzaju (jak np. faktycznie rażąca dysproporcja między wskazanymi korzyściami i kosztami albo praktyczna niemożność ograniczenia przez władzę państwową tych ostatnich poprzez podjęcie działań alternatywnych wobec nakładania normatywnych restrykcji na wolność wypowiedzi).

Konkludując ten fragment rozważań, warto też wyeksponować antyperfekcjonistyczny i antypaternalistyczny wymiar omawianej argumentacji. Po pierwsze, przynajmniej implicite, wiąże się z nią rezygnacja z dążenia do zabezpieczonego przymusem państwa doskonalenia dyskursu publicznego, w wyniku którego wszystkie występujące w debacie punkty widzenia byłyby racjonalne, dobrze uargumentowane, sformułowane bona fidei, respektujące godność interlokutora oraz zaprezentowane w odpowiedniej - nieobraźliwej - formie. Nawiązując do cytowanego wyżej orzeczenia ETPCz, również opinie oburzające, obrażające, bulwersujące i prowokujące różnego autoramentu konflikty zasługują na miejsce w publicznej konwersacji. Po drugie, analizowany argument opiera się na presumpcji, zgodnie z którą próba dyktowania przez władzę (przy użyciu przymusu prawnego) obywatelom, jakie poglądy są akceptowalne, jest świadectwem pogardy względem nich oraz wiąże się z odmówieniem ludziom należnego im szacunku ${ }^{12}$. Godzi się nadmienić, że taka antypaternalistyczna teza może się koncentrować wokół uprawnień przysługujących zarówno nadawcy danego komunikatu, jak i jego odbiorcy. Z jednej bowiem strony możliwość swobodnego wyrażania osobistych przekonań i uczuć jest centralnym składnikiem egzystencji ludzi jako niezależnych podmiotów, manifestujących tym sposobem swoją osobowość ${ }^{13}$; z drugiej, ingerencja państwowa uniemożliwiająca jednostce zapoznanie się z jakimikolwiek poglądami bądź też odczuciami mogącymi przyczynić

${ }^{10}$ R. Dworkin, Freedom 's Law: the Moral Reading of the American Constitution, Cambridge 1996, s. 200-201.

11 R. Dworkin, Matter of Principle, Cambridge 1985, s. 353 n.

12 G.E. Carmi, Dignity - the enemy from within: a theoretical and comparative analysis of human dignity as a free speech justification, „Journal of Constitutional Law” 9, 2007, s. 973.

13 Ibidem, s. 974; K. Greenawalt, Free Speech justifications, „Columbia Law Review” 89, 1989, s. 153. Jak wskazuje Sadurski, swoboda wypowiedzi „,is crucial for self-fulfillment because the exercise of our capacities is only made possible through self-definition, and the determination of 
się do samodzielnego formułowania przez nią własnego stanowiska w określonej sprawie wymusza na człowieku dostosowanie się do opinii innych podmiotów w kwestii moralnej oceny danej aktywności komunikacyjnej, pozbawiając go tym samym szansy na samodzielne i niezależne dojście do konkluzji w przedmiotowej sprawie ${ }^{14}$. Sądzę, że to właśnie antypaternalistyczny wymiar omawianej racjonalizacji czyni immanentnie niemożliwym wykorzystanie jej w celu legitymizacji ograniczeń wolności słowa (czego nie można powiedzieć o kolejnych tezach ${ }^{15}$ ).

Legitymizacja wolności słowa jako najlepszego instrumentu służącego poszukiwaniu i odkrywaniu prawdy dotyczy przede wszystkim obszaru episteme. W sposób bodaj najbardziej dobitny w całej filozofii politycznej przeświadczenie to zostało wyrażone w pismach Johna Miltona i Johna Stuarta Milla. W ocenie tych anglosaskich myślicieli prawda jest odkrywana (a nawet konstytuuje się) w wyniku dyskusji, debat, polemik, sporów i kontrowersji, a dążenie do jej poznania jest utrudniane czy wręcz uniemożliwiane przez odgórną dekretację dowolnej ortodoksji, niezależnie od jej substancjalnej zawartości. Jak emfatycznie perorował pierwszy z nich, ,prawda nie potrzebuje żadnych polityk, żadnych strategii, żadnego koncesjonowania prasy, aby zwyciężyć. To wszystko są zabiegi i matactwa, którymi posługuje się błąd w celu przeciwstawienia się sile prawdy. Dajmy jej przestrzeń i nie wiążmy jej, gdy zapada w sen". Zdaniem Miltona należy zezwolić Prawdzie na zmaganie się z Fałszem; nie ma powodu, by powątpiewać w triumf tej pierwszej w otwartym i uczciwym pojedynku, nawet jeśli pozwolić „,wszelkim wichrom doktrynalnym hulać na ziemi" ${ }^{16}$.

who we really are is impossible without open communication with our fellow human beings" (idem, Freedom..., s. 17).

${ }^{14}$ K. Greenawalt, op. cit., s. 150-152.

15 Jeżeli uznajemy legitymizowanie zasady swobody wypowiedzi przez argumentację z autonomii jednostki za - choćby częściowo - prawomocne, to nałożenie na sferę ekspresyjną ewentualnych prawnych restrykcji musi być umotywowane odmiennymi względami (tj. potrzebą zabezpieczenia innych cennych, a w danym przypadku konkurencyjnych wobec wolności słowa wartości). Sytuacja przedstawia się zgoła inaczej w odniesieniu do uzasadnień przyznających swobodzie wypowiedzi czysto służebną rolę. Jeśli zaakceptujemy słabsze (to konieczne zastrzeżenie) wersje takich argumentów, to mogą one same w sobie dostarczać uprawomocnienia dla cenzurowania lub kryminalizowania ekspresji. Przykładowo, skoro wolność słowa ma służyć poszukiwaniu prawdy, to nie widać powodu, dla którego niedopuszczalne miałoby być penalizowanie wypowiedzi ewidentnie fałszywych oraz „mącących ludziom w głowach” (choćby „kłamstwa oświęcimskiego”); skoro wolność słowa ma służyć zasadom demokracji, to nie widać powodu, dla którego niedopuszczalne miałoby być prawne zwalczanie głoszenia doktryn autorytarnych i totalitarnych (choćby propagowanie faszyzmu); skoro wolność słowa ma służyć stworzeniu tolerancyjnego społeczeństwa, to nie widać powodu, dla którego — zgodnie z wymownym historycznym powiedzeniem „nie ma tolerancji dla wrogów tolerancji” — niedopuszczalne miałoby być represjonowanie ekspresji bigoteryjnej, homofobicznej, antysemickiej lub też promującej nienawiść rasową.

16 J. Milton, Areopagitica, [w:] The Principles and Practice of Freedom of Speech, red. H.A. Bosmajian, Boston 1971, s. 32-33. 
Argumentacja Millowska jest jeszcze silniejsza (oczywiście w filozoficznym sensie). Obok przywołania klasycznych dla nieufnych i sceptycznych wariantów liberalizmu argumentów z niepewności poznawczej oraz naturalnej nieostateczności i prowizoryczności każdego osądu ludzkiego, które nie pozwalają finalnie i ultymatywnie odróżnić prawdy od błędu, Mill stwierdził zarazem, że każda opinia wywołuje określone społeczne korzyści. O ile profity dla jednostek i zbiorowości płynące ze swobody wyrażania poglądów prawdziwych nigdy nie były przynajmniej in abstracto - poważnie kwestionowane, o tyle nieprzemijającym wkładem angielskiego myśliciela do idei wolności słowa jest dostrzeżenie wartościowości wypowiedzi fałszywych. Jak pisał Mill, ,jeśli opinia nie jest w pełni, często i bez lęku dyskutowana, to będzie wyznawana jako martwy dogmat, a nie jako żywa prawda". Arbitralne odgórne dekretowanie jakiejkolwiek ortodoksji powiązane nieuchronnie z prześladowaniem stanowisk ,heretyckich” powoduje, że prawda przekształca się przypadkowo w akceptowany przesąd, nieuzasadniony racjonalnymi przesłankami. Według Milla ludzie muszą być permanentnie gotowi na konfrontowanie swoich przekonań z tezami oponentów w ich najbardziej autentycznej, perswazyjnej i wiarygodnej formie; w przeciwnym bowiem razie ryzykujemy utracenie „lepszego postrzegania i silniejszego oddźwięku prawdy wywołanego jej zderzeniem z błędem"17. Tej adhortacji przyświeca niewypowiedziana wprost wizja społeczeństwa jako sui generis klubu dyskusyjnego, którego członkowie są gotowi do ciągłej weryfikacji swoich poglądów oraz do nieustannego udziału w zbiorowej rozmowie.

Argument $\mathrm{z}$ poszukiwania prawdy może funkcjonować w wariancie mocnym i słabym (co nasuwa skojarzenie z dobrze ugruntowanym naukowo rozróżnieniem liberalizmu odwagi od liberalizmu strachu ${ }^{18}$ ). Jako egzemplifikację pierwszego ujęcia można potraktować słowa Thomasa I. Emersona, który, rekonstruując analizowane tu stanowisko, konstatuje, że

osoba poszukująca wiedzy i prawdy musi zapoznawać się ze wszystkimi punktami widzenia w danej sprawie, musi rozważać wszystkie alternatywy, musi testować swój osąd przez wystawienie go na konfrontację z osądami przeciwnymi i musi czynić pełny użytek z różnych koncepcji. Dyskusja musi być otwarta niezależnie od tego, jak pewny może wydawać się akceptowany powszechnie pogląd; wiele z jak najszerzej aprobowanych prawd okazywało się w przyszłości błędnymi. I odwrotnie, taką samą regułę należy zastosować niezależnie od tego, jak fałszywy lub też niebezpieczny wydaje się pogląd nowy, albowiem może on okazać się prawdziwy czy częściowo prawdziwy, a nawet jeżeli jest on w całości fałszywy, to i tak jego przedstawienie i otwarte przedyskutowanie wymusza ponowne przemyślenie i [ewentualną — Ł.M.] weryfikację poglądów ortodoksyjnych ${ }^{19}$.

Podobną supozycję — na gruncie praktyki sądowej — przedstawił sędzia Sądu Najwyższego Stanów Zjednoczonych Oliver Wendell Holmes:

17 J.S. Mill, op. cit., s. 35, 65, 66, 68.

18 Por. M. Król, Liberalizm strachu czy liberalizm odwagi, Kraków-Warszawa 1996, passim.

19 T.I. Emerson, op. cit., s. 6-7. 
Prześladowanie za poglądy wydaje mi się w pełni logiczne. Jeśli nie żywisz żadnych wątpliwości co do swych przekonań oraz swojej władzy i jeśli całym sercem pragniesz osiągnąć określony rezultat, to wówczas w naturalny sposób dążysz do przekształcenia swoich życzeń w prawo i do zmiecenia wszelkiej opozycji [...] Kiedy jednak ludzie uświadomią sobie, iż czas podważa wiele mocnych wierzeń, to wówczas mogą zdać sobie sprawę, że [...] najlepszym testem dla prawdziwości danej myśli jest jej zdolność do bycia zaakceptowaną po triumfie w rynkowej konkurencji ${ }^{20}$.

Słabsza wersja omawianego uzasadnienia jest natomiast oparta na określonym bilansie probabilistycznym oraz utylitarnej kalkulacji dotyczącej alternatywnych rozwiązań, jakimi są poszanowanie swobody wypowiedzi oraz szeroko zakrojone nadzorowanie dyskusji publicznej przez państwo. Jak wskazał np. inny wybitny amerykański jurysta Learned Hand, koncepcja wolności słowa może zostać usprawiedliwiona prostym domniemaniem, zgodnie z którym ,poprawne wnioski z większym prawdopodobieństwem wyłaniać się będą z mnogości języków niż z powodu jakiegokolwiek rodzaju autorytatywnej selekcji"21.

Ta supozycja dobrze komponuje się ze słowami konstytucjonalisty Fredericka Schauera, w którego przekonaniu wolny rynek idei nie zawsze jest efektywnym instrumentem służącym eksploracji i poznaniu prawdy, co wyraźnie demonstruje historia, przepełniona przykładami zbiorowych szaleństw, manii, psychoz, zbrodni i obsesji, mających swe pierwotne źródło w sferze werbalnej. Mimo to arbitralne przesądzanie prawdy przez władzę państwową również historycznie udowodniło swoją nieskuteczność; co więcej, przyjęcie tego rozwiązania groziłoby zdecydowanie bardziej niebezpiecznymi konsekwencjami aniżeli selekcja pierwszego wariantu $^{22}$. Z tej perspektywy zasada poszanowania wolności słowa okazuje się wielce niedoskonałym, ale komparatywnie najlepszym, sposobem urzeczywistnienia generalnego celu, jakim jest odkrycie prawdy.

Prima facie analizowane uzasadnienie wydaje się odnosić wyłącznie do wypowiedzi zawierających choćby rudymentarnie deskryptywną treść. Argumentacja ta — w jej ścisłym rozumieniu — dotyczyłaby tedy jedynie stwierdzeń faktycznych, a nie opinii czy manifestacji stricte emocjonalnych. Ekspresja drugiego rodzaju - jako ex definitione niefalsyfikowalna i nieweryfikowalna w sensie logicznym - nie może przecież przyczyniać się do zrealizowania wskazanego tutaj celu ${ }^{23}$. W mojej ocenie tak drastyczne zawężenie relewantności argumentu z prawdy jest jednak bezzasadne. Jeżeli bowiem wyjdziemy poza klasyczne arystotelesowskie korespondencyjne pojmowanie prawdy jako zgodności opisu z rzeczywistością, to - jak sądzę - wypowiedzi o charakterze opinii, ekspresja emocjonalna itp. nie są całkowicie indyferentne z perspektywy wskazanego powyżej

20 Abrams vs. United States, 250 U. S. 616 (1919).

21 Cyt. za: P. Garry, An American Paradox: Censorship in a Nation of Free Speech, Westport 1993, s. 41.

22 F. Schauer, Free Speech: a Philosophical Enquiry, New York 1982, s. 34; idem, Reflections on the value of truth, „Case Western Reserve Law Review” 41, 1991, s. 704-705.

23 W. Sadurski, Offending with Impunity: Racial Vilification and Freedom of Speech, „Sydney Law Review" 14, 1991, s. 174. 
kryterium. Swobodna debata w sprawach politycznych, kulturalnych czy ekonomicznych, obejmująca prawo do formułowania subiektywnych ocen, przesądów, odczuć czy emocji, ułatwia bowiem dyskutantom lepszą eksplikację i zrozumienie treści, konsekwencji, wad oraz zalet poszczególnych stanowisk, przybliżając ich tym samym do rzetelniejszego oraz bardziej pogłębionego spojrzenia na istniejące realia. Trudno przecież odmówić wolnej debacie między np. zwolennikami demokracji i totalitaryzmu, orędownikami i przeciwnikami przymusowych ubezpieczeń społecznych bądź też adwokatami i oponentami idei tolerancji religijnej jakiejkolwiek wartości informacyjnej (nawet jeśli jest ona wyłącznie przepełnioną emocjami prezentacją wzajemnie nieprzystawalnych do siebie narracji). Także osoby obserwujące takową wymianę poglądów mogą uzyskać dodatkową wiedzę dotyczącą wewnętrznej spójności określonych koncepcji, konsekwencji ich potencjalnego zastosowania $\mathrm{w}$ danej zbiorowości politycznej, ich aksjologicznych i doktrynalnych fundamentów itp.

Argument $\mathrm{z}$ inherentnego powiązania swobody ekspresji z systemem ludowładztwa wykracza poza banalne spostrzeżenie, zgodnie z którym ustrój demokratyczny opiera się na wolnych wyborach, w których konkurencyjne opcje polityczne mają równe (przynajmniej ze ściśle formalnego punktu widzenia) szanse przedstawienia opinii publicznej proponowanych przez siebie programów, a obywatele mają równocześnie możliwość współuczestnictwa w dyskusji o sprawach publicznych i do krytykowania swych przywódców w nieskrępowanej, żywej, opartej na zasadzie równości i otwartej debacie, nie ponosząc przy tym ryzyka natury prawnej czy fizycznej24. Zwolennicy wskazanego uzasadnienia zwykle pojmują demokrację $\mathrm{w}$ substancjalnych — a nie jedynie proceduralnych - kategoriach, czyli jako system polityczny pozwalający jednostkom na skorzystanie w pełni z ich pozytywnej - w Berlinowskim bądź też Hayekowskim sensie wolności suwerennego kształtowania ładu społeczno-politycznego ${ }^{25}$.

Jak dowodzi Cass R. Sunstein, wolność słowa i swobodna wymiana poglądów, gwarantujące otrzymywanie przez obywateli kształtujących ich preferencje informacji, opinii i punktów widzenia ze zróżnicowanych źródeł, stanowią warunek sine qua non systemu deliberatywnej demokracji, w której decyzje polityczne (w największym możliwym stopniu) odzwierciedlają poglądy i życzenia opinii publicznej. Celem demokratycznej polityki nie jest tutaj jedynie objęcie ochroną pierwotnych wobec społeczeństwa jednostkowych praw, odzwierciedlenie nacisków wywieranych przez pewne grupy interesów, zagregowanie istniejących prywatnych preferencji czy odnalezienie kompromisu wymuszane agonistycznym wymiarem publicznej debaty. Deliberatywna demokracja jest natomiast ufundowana na założeniu, zgodnie z którym jednostki dysponują uprawnieniem do kreowania rzeczywistości społecznej (niekoniecznie $a b$ ovo) na podstawie indywidu-

24 S.H. Shiffrin, Dissent, Injustice, and the Meanings of America, Princeton 2000, s. 42.

25 S. Breyer, Active Liberty: Interpreting our Democratic Constitution, New York 2005, s. 15, 42. 
alnych i racjonalnych (instrumentalnie) osądów, ukształtowanych m.in. w wyniku wolnego ,procesu komunikacyjnego dotyczącego spraw publicznych, zachodzącego zarówno między obywatelami, jak i między obywatelami a ich przedstawicielami”. Zgodnie z takim ujęciem, ograniczenie wolności słowa, pozbawiając ludzi dostępu do już to określonych informacji, już to do określonych stanowisk ideologicznych, już to do określonych punktów widzenia, redukuje ich suwerenną zbiorową wolność i zmniejsza szansę na stworzenie ustroju responsywnego wobec rzeczywistych pragnień, aspiracji i celów danej zbiorowości ${ }^{26}$. Warto w tym miejscu dodać, że — moim zdaniem — argument z demokracji nie odnosi się wyłącznie do politycznej ekspresji w ścisłym znaczeniu terminu. Po pierwsze, dyferencjacja twierdzeń politycznych i niepolitycznych jest niesłychanie trudna i arbitralna (a niekiedy być może w ogóle niemożliwa). Po drugie, wypowiedzi artystyczne, naukowe, filozoficzne czy literackie niejednokrotnie wywierają przecież namacalny wpływ na rozstrzygnięcia podejmowane przy urnie wyborczej, modelując wrażliwość, inteligencję i wiedzę uczestników demokratycznego procesu ${ }^{27}$. Argument z demokracji może więc dotyczyć każdej komunikacji odnoszącej się do szeroko rozumianej materii publicznej (poruszającej zagadnienia istotne dla zbiorowości) lub kształtującej indywidualną osobowość nadawców i odbiorców danego przekazu (choćby przy użyciu metaforycznych, artystycznych, literackich czy symbolicznych środków wyrazu).

Podobnie jak uzasadnienie z poszukiwania prawdy, argument z demokracji też wydaje się osadzony w wizji wolnego społeczeństwa jako swoistego klubu dyskusyjnego. Analogię tę dobitnie wyłożył Alexander Meiklejohn, amerykański filozof i pedagog (ta druga profesja jest w interesującym nas kontekście niepozbawiona wagi). $\mathrm{W}$ jego mniemaniu rdzeniem wolności politycznej jest obywatelskie prawo do samorządności. Meiklejohn był przekonany, iż model państwa funkcjonujący w Stanach Zjednoczonych jest — na poziomie teorii konstytucyjnej, a niekoniecznie rzeczywistej praxis - wcieleniem pryncypium politycznego samostanowienia, zgodnie z którym każdy obywatel (dysponujący prawem wyborczym) jest zarazem rządzącym oraz rządzonym ${ }^{28}$. Filozof porównał ten system rządów do zgromadzenia członków lokalnej wspólnoty, podczas którego mieszkańcy

gromadzą się, by przedyskutować i podjąć działania dotyczące zagadnień publicznych: dróg, szkół, przytułków, zdrowia, obrony przed agresją zewnętrzną itd. Każdy, kto tego chce, może przybyć na zebranie. Wszyscy są politycznie równi. Każdy posiada uprawnienie oraz obowiązek samodzielnego myślenia, wyrażania swej opinii, wysłuchania argumentów innych osób. Podstawową regułą jest nienaruszanie wolności słowa.

26 C.R. Sunstein, Democracy and the Problem of Free Speech, New York 1993, s. 18-19, 244. Szerzej na temat ,responsywnej demokracji” zob. np. R.C. Post, Constitutional Domains: Democracy, Community, Management, Cambridge 1995, s. 191-192.

27 A. Meiklejohn, The first amendment is an absolute, „Supreme Court Review” 1961, s. 256-257.

28 A. Meiklejohn, Free Speech and its Relation to Self-Government, New York 1948, s. 3. 
Oczywiście na takim spotkaniu jego uczestnicy nie mogą wypowiadać się w sposób całkowicie swobodny (czyli kiedykolwiek chcą, na dowolny temat, w dowolnej formie itp.); przyjęcie takiego założenia wiodłoby wprost do anarchizacji systemu i niemożności podjęcia jakiejkolwiek decyzji. Wolność słowa uczestników debaty sprowadza się więc do możliwości merytorycznego udziału w rozmowie o wszelkich kwestiach będących przedmiotem zebrania. Równocześnie jednak, pod warunkiem zachowania przez mówcę stosownego decorum, nikt nie ma kompetencji do ingerowania w treść takowej wypowiedzi czy jej cenzurowania ${ }^{29}$.

Według Meiklejohna, aby procedura kolektywnego podejmowania decyzji mogła prowadzić do osiągnięcia rozumnego rezultatu, obywatele muszą mieć świadomość, „nad czym głosują. To z kolei wymaga, aby [...] wszystkie fakty oraz racje odnoszące się do danego problemu zostały całościowo i rzetelnie przedstawione". Tylko wówczas ludzie są w stanie racjonalnie wybrać określoną linię postępowania spośród palety dostępnych alternatyw. Meiklejohn pisał, iż żaden punkt widzenia nie może być sprawiedliwie wykluczany z debaty jedynie dlatego, że jej inni uczestnicy uznają go za fałszywy lub niebezpieczny. W jego przeświadczeniu, „kiedy jednostki się samo-rządzą, to właśnie one — i nikt inny — pełnią funkcję arbitra w kwestii głupoty, niesprawiedliwości i niebezpieczeństwa. A to z kolei oznacza, że niemądre poglądy muszą być wysłuchane tak samo, jak mądre, niesprawiedliwe jak sprawiedliwe, niebezpieczne jak niepowodujące zagrożenia". Pozbawianie obywateli szansy zapoznania się z ,informacją, opinią, wątpliwością, niewiarą lub krytycyzmem" w jakiejś sprawie publicznej to okaleczanie procesu demokratycznej deliberacji. Wolni ludzie, egzystujący w wolnym społeczeństwie, nie mogą lękać się słów ${ }^{30}$. Swoboda wypowiedzi obejmuje zatem wszelką ekspresję zorientowaną na realizację dobra publicznego, niezależnie od tego, czy mówca „zaleca bądź oprotestowuje przymusowy pobór do sił zbrojnych, opowiada się za wojną bądź przeciwko niej, broni bądź atakuje demokrację, proponuje bądź krytykuje reorganizację gospodarki w oparciu o doktrynę komunizmu"31.

Jak konkludował Meiklejohn, wolność słowa nie jest jedynie indywidualnym uprawnieniem wynikającym z konieczności poszanowania ekspresyjnej autonomii jednostek, lecz przede wszystkim instrumentem zapewniającym obywatelom możliwie jak najpełniejszą możliwość ,zrozumienia problemów, z jakimi borykają się członkowie stanowiącej o sobie zbiorowości" 32 . W tym ujęciu wolność słowa okazuje się konstytutywnym elementem ustroju demokratycznego, nieodzownym składnikiem realnego deliberatywnego ludowładztwa.

29 Ibidem, s. 22-25. Zauważmy ponadto, iż przyznanie niektórym jednostkom prawa do limitowania wolności słowa innych osób implicite podminowuje zasadę politycznej równości. Por. R. Dworkin, Political equality, [w:] Philosophy and Democracy: an Anthology, red. T. Christiano, New York 2003, s. 123.

\footnotetext{
30 A. Meiklejohn, Free Speech..., s. 25-27.

31 Ibidem, s. 45-46.

32 Ibidem, s. 63, 88.
} 
Podstawą argumentu z progresywnej roli swobody wypowiedzi jest spostrzeżenie, że wolna i rzetelna debata, oparta na konfrontacji przeciwstawnych argumentów, kreuje większą szansę na przyjęcie korzystnych rozwiązań określonych problemów aniżeli ich autorytatywne oktrojowanie. Przykładowo, selekcja polityki gospodarczej powinna następować po dyskusji pomiędzy ekonomistami reprezentującymi różne paradygmaty myślenia; ustawodawca winien dokonać wyboru pomiędzy opozycyjnymi propozycjami legislacyjnymi po ich pieczołowitym rozważeniu; kierunki polityki zagranicznej danego państwa powinny być rezultatem uczciwej debaty pomiędzy orędownikami rozmaitych alternatyw. Podobna prawidłowość występuje też w innych obszarach ludzkiego doświadczenia aniżeli polityka czy ekonomia. Najwybitniejsze dzieła literackie powstały przecież na kanwie konfliktów kulturowych pomiędzy rzecznikami odmiennych prądów ${ }^{33}$. Progres nie polega zatem tylko na zidentyfikowaniu czy implementacji konkretnych rozwiązań, lecz także na poszerzeniu perspektywy, pobudzeniu wrażliwości bądź wywołaniu przemian w mentalności społecznej. Warto zauważyć, iż postęp nie musi być tutaj pojmowany w kategoriach linearnej progresywnej historiozofii; w partykularnej sytuacji może równie dobrze oznaczać powrót do uprzednio zarzuconych punktów widzenia. Ostatecznie, respektowanie wolności słowa pozwala, jak pisze Thomas I. Emerson, stworzyć „wspólnotę w większym stopniu zdolną do adaptacji, a przez to stabilniejszą [...] podczas gdy thumienie swobodnej ekspresji promuje brak elastyczności i marazm, uniemożliwiając społeczeństwu dostosowanie się do zmieniających warunków lub rozwinięcie nowych koncepcji". Co więcej, mechanizm wolności słowa skłania osoby ,przegrane” w takowych dysputach do łatwiejszego pogodzenia się z porażką (wzięły bowiem udział w procesie decyzyjnym i uzyskały okazję do zaprezentowania swego stanowiska), rozładowując tym samym potencjalne konflikty między triumfatorami sporu a stroną przeciwną i stymulując społeczną spoistość ${ }^{34}$.

Nietolerancja ideologiczna, polityczna, religijna czy nawet estetyczna stanowi jedną z najczęstszych przesłanek skłaniających decydentów do wprowadzania rozmaitych ograniczeń wolności słowa (już to z powodu autentycznie wyznawanych przez nich przekonań, już to dla złożenia hołdu nietolerancyjnym impulsom występującym w danej zbiorowości). A contrario, związek między poszanowaniem swobody wypowiedzi i ideą szeroko rozumianej tolerancji jest też niezwykle silny. Wymóg tolerowania przez państwo negatywnie waloryzowanych wypowiedzi jest wszak logicznym skutkiem udzielenia aprobaty uzasadnieniom z autonomii, poszukiwania prawdy i demokracji ${ }^{35}$.

${ }^{33}$ Na myśl przychodzi tu w szczególności spór między reprezentantami oświecenia a romantykami czy też przedstawicielami tej drugiej grupy a pozytywistami.

34 T.I. Emerson, op. cit., s. 7.

35 Por. R. Cohen-Almagor, The Boundaries of Liberty and Tolerance: the Struggle against Kahanism in Israel, Gainesville 1994, s. 106-107. 
Ostatnia $\mathrm{z}$ omawianych $\mathrm{w}$ ramach artykułu legitymizacji wiąże się jednak z przyznaniem tolerancji wartości autonomicznej. Trzeba bowiem zauważyć, że powiązanie między obydwoma konceptami jest dwukierunkowe. $Z$ jednej strony, postawa tolerancyjna automatycznie implikuje szeroki zakres swobody wypowiedzi; z drugiej zaś przestrzeganie zasady wolności słowa może ewokować przyrost tolerancji. Na drugi aspekt tej relacji zwraca uwagę Lee C. Bollinger. W jego ocenie naturalnym odruchem człowieka jest „impuls nadmiernej nietolerancji” wobec nieaprobowanych zachowań i ekspresji, wynikający z niejako instynktownej niechęci względem osób „postrzeganych jako inne, wyznających inne wartości i przekonania, wybierających inny sposób życia”. Pohamowanie takiej reakcji — choć oczywiście nie jej totalne wyeliminowanie (impuls ów może być wykorzystany w społecznie użyteczny sposób) — którego manifestacją jest przestrzeganie zasady wolności słowa, pozwala wykształcić w człowieku „osobowość demokratyczną" 36 . Jak dowodzi Bollinger, podstawowe charakterologiczne cechy takiego osobnika to poszanowanie prawa innych osób do posiadania odmiennych poglądów, skłonność do zawierania kompromisów oraz gotowość do akceptacji przegranej w politycznej rywalizacji. Te umysłowe dyspozycje, zakładające wolę rezygnacji z urzeczywistniania własnych celów za wszelką cenę w imię utrzymania spoistości wspólnoty, mają fundamentalne znaczenie dla długofalowego przetrwania zbiorowości. Inaczej mówiąc, respektowanie swobody wypowiedzi „ma na celu pomóc nam w uzyskaniu kontroli nad uczuciami relewantnymi do całej tkanki stosunków społecznych", a nie jedynie ochraniać ekspresyjne uprawnienia indywidualne. Bollinger wskazuje zatem, iż uzasadnieniem wolności słowa jest potrzeba odpowiedniego skorygowania defektu w naszym naturalnym usposobieniu intelektualnym ${ }^{37}$. Dla amerykańskiego filozofa poszanowanie wolności słowa staje się przeto instrumentem swoistej inżynierii społecznej, mającym zmodyfikować ludzki sposób myślenia i odczuwania (i to — przynajmniej moim zdaniem - w wielce radykalnym wymiarze $\left.{ }^{38}\right)$.

Przeanalizowane powyżej argumenty doktrynalne na rzecz szerokiego zakresu swobód ekspresyjnych nie wyczerpują katalogu uzasadnień przemawiających za ideą wolności słowa. Mogą być bowiem uzupełnione doniosłymi racjami natury praktycznej. Po pierwsze, supresja określonych poglądów może prowadzić — zgodnie z zasadą równi pochyłej — do nieustannego rozrostu kompetencji regulacyjnych państwa. Po drugie, przyznanie aparatowi państwowemu uprawnień cenzorskich bądź kryminalizacyjnych stwarza ryzyko ich nadużywania przez sądy lub też organy administracyjne. Po trzecie, ograniczanie wolności wypowiedzi niekoniecznie prowadzi do eliminacji niepożądanych poglądów, ale częściej po-

36 Wydaje się, iż pojęcie to ma stanowić kontrapunkt wobec adornowskiego syndromu autorytarnego.

37 L.C. Bollinger, The Tolerant Society: Freedom of Speech and Extremist Speech in America, New York 1986, s. 107, 111, 116-120.

38 Por. J. Shearmur, The Political Thought of Karl Popper, New York 1996, s. 40-44. 
woduje tylko ich zniknięcie z forum publicznego, co z kolei utrudnia oponentom podjęcie rzetelnej polemiki. Po czwarte, z konieczności selektywne penalizowanie nieakceptowanej ekspresji kreuje problemy z punktu widzenia zasady równości ludzi wobec prawa. Po piąte, osoby prześladowane za wyrażanie swoich — choćby odrażających - przekonań mogą zostać otoczone nimbem męczenników za wolność słowa, co z kolei kreuje istotne ryzyko wzrostu popularności wygłaszanych przez nie supozycji (zgodnie z zasadą kuszącego — bo zakazanego - owo$\mathrm{cu}$ ), aczkolwiek takich argumentów nie należy bagatelizować, jednak kluczowe znaczenie dla zdeterminowania statusu wolności słowa w danej wspólnocie politycznej powinny mieć legitymizacje doktrynalne. W mojej ocenie siła perswazyjna tych ostatnich okazuje się znaczna. Nie znaczy to oczywiście, że w sytuacji konfliktu pomiędzy wolnością słowa a innymi cennymi wartościami (godność człowieka, bezpieczeństwo państwa czy obywateli, pokój społeczny, moralność itp.) zawsze musimy przyznawać priorytet swobodzie wypowiedzi. Takie rozstrzygnięcie będzie stanowić w każdych okolicznościach wypadkową indywidualnych preferencji aksjologicznych. Jednak waga idei wolności słowa, zarówno na poziomie jednostkowym, jak i ogólnospołecznym, wymaga, by zawsze — mówiąc językiem Dworkina — traktować poważnie powstałe na jej tle roszczenia.

\section{DOCTRINAL JUSTIFICATIONS OF THE FREEDOM OF SPEECH}

\section{Summary}

Freedom of speech is one of the foundational values of contemporary liberal and democratic systems. The article analyzes four most important doctrinal justifications for extending a far-reaching protection for expression. First, respect for free speech is a logical corollary and consequence of respecting individual dignity and liberty. Second, free market of ideas is the best way of attaining truth and fostering healthy public debate. Third, freedom of speech is an indispensable condition of democratic political system. Fourth, respecting free speech helps create tolerant and open-minded society. 